Volume 1, No. 3, September - December 2016 ISSN: 2503-4235 (p); 2503-4243 (e)

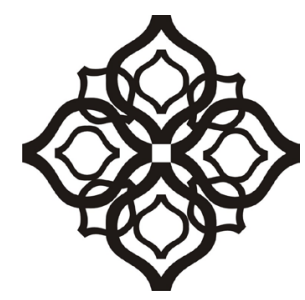

Shirkah

Journal of Economics and Business 


\section{Shirkah}

\section{Journal of Economics and Business \\ Vol. 1, No. 3, September-December 2016 \\ ISSN: 2503-4235 (p); 2503-4243 (e)}

\section{Editor in Chief}

Sri Walyoto

\section{Editorial Boards}

Abu Umar Faruq Ahmad, UBD School of Business and Economics, Brunei Darussalam

Amelia Fauzia, Asia Research Institute, National University of Singapore, Singapore

Cedomir Nestorovic, ESSEC Business School Asia Pacific, Singapore

Dwi Condro Triono, Faculty of Islamic Economics and Business, IAIN Surakarta, Indonesia

Fahmy Radhi, Faculty of Economics and Business Universitas Gadjah Mada, Yogyakarta, Indonesia

Hasan Basri, Syiah Kuala University, Aceh, Indonesia

Jaka Sriyana, Faculty of Economics, Universitas Islam Indonesia, Yogyakarta, Indonesia

Johan Fischer, Department of Social Sciences and Business Roskilde University, Denmark

Masudul Alam Choudhury, Postgraduate Program in Islamic Economics and Finance, Trisakti University, Jakarta, Indonesia and the College of Economics and Political Science (CEPS) in Sultan Qaboos University (SQU), Oman

M. Falik Isbah, School of Humanities and Social Science, University of New South Wales, Australia

M. Ishaq Bhatti, La Trobe Business School Department of Economics and Finance La Trobe University, Australia

Nunung Nurul Hidayah, Aston Business School, Aston University, Birmingham, United Kingdom

Najib Kailani, Pascasarjana, Universitas Islam Negeri (UIN) Sunan Kalijaga, Yogyakarta, Indonesia

Shaikh M Ghazanfar, Departement of Economics, University of Idaho, Russian Federation 
Managing Editors

M. Endy Saputro

M. Zainal Anwar

\section{Assistant to Editor}

Supriyanto

Shirkah Journal of Economics and Business is a peer-reviewed journal published three times a year (January-April, May-August and September-December) by Faculty of Islamic Economics and Business, Institut Agama Islam Negeri (IAIN/ State Institute for Islamic Studies) Surakarta Central Java, Indonesia. The main objective of Shirkah is to offer an academic space of exchange ideas and initiate the increase number of qualified article produced by postgraduate students, practitioners and academicians.

\section{Editorial Office}

Ruang Jurnal Shirkah

Lantai Dasar, Sayap Barat, Fakultas Ekonomi dan Bisnis Islam, IAIN Surakarta

Jln. Pandawa No. 1, Kartasura, Sukoharjo, Jawa Tengah Kode Pos. 57168

Phone (+62271) 781516 Fax: (+62271)782336

E-mail: shirkahiainsurakarta@gmail.com

Website: http://shirkah.or.id/ 



\section{Shirkah}

\section{Journal of Economics and Business}

Vol. 1, No. 3, September-December 2016

ISSN: 2503-4235 (p); 2503-4243 (e)

\section{Table of Contents}

\section{Articles}

Muhfiatun

The Effect of Sharia Monetary Policy and Financing Quality on Financial Performance in Sharia Banking

Roro Hindun

Izzul Fatchu Reza

Understanding Indonesian People Borrowing Money

from Banks and Non-Banking Institutions

M. Nur Rianto Al Arif

299

Monopoly and Ikhtikar in Islamic Economics

Trimulato

Sharia Bank Product Development through Mudhrabah Investment

Aida Nurul Hadiah

Financial Services Authority (OJK) Policy on Debt Proportion and Its Impact on the Profitability of DES Listed Companies in Indonesia

Statement of Financial Accounting Standard (PSAK)

No. 109 and Its Implementation in Several Zakat Management

Organizations in Malang, East Java 



\title{
Sharia Bank Product Development through Mudhrabab Investment
}

\author{
Trimulato \\ Universitas Islam Makassar
}

\begin{abstract}
Sharia banking now has a strong legal framework with the presence of law number 21 of 2008 on sharia banking in Indonesia. This regulation enforces sharia banking to develop products to achieve the targeted market share of 5\%. In third-party fund products, more innovation is needed to attract people to entrust their funds in sharia banks. The visible data of mudharabah fund raising deposit products in March 2013 amounted to Rp100.746.000.000 and Rp115.728.000.000 in mudharabah deposits was visible on April 2014, which is an increase of less than 2\% each month. This research uses a qualitative descriptive methodology, and is focused on fund raising products in sharia banking, particularly in the form of mudharabah investments for a definitive result. The results show that sharia banking requires innovative fund raising for third-party products, such as mudharabah investment products. These investments provide certainty of results despite using mudharabah and are based on the certainty that projector financing has been agreed by the sharia with the creditor banks. This investment product can be offered to both individuals and groups/collectives.
\end{abstract}

Keywords: sharia banking, investment, mudharabah

Yuli Anisah, in her research entitled Effect of Profit Sharing System Against Customer Interest To Invest in Baitul Maal Wa Tamwil (BMT) in Banda Aceh, concluded that profit sharing creates a desire to invest showing 0,452 at 1 percent significance level. Hypothesis testing found that $\mathrm{Ha}$ is received, which means that between $\mathrm{x}$ to $\mathrm{y}$ there is significant influence. A revenue sharing system in syariah financial institutions gave affect to the interest of the customer to embed instituted Islamic financial 
saving such as BMT. From year to year, there have been continual increases in the number of customers (Anisah, 2012, p. 6).

Yudho Prabowo mentions that mudaraba investment deposits in Bank Syari'ah Mandiri tend to gain profit caused by VaR (zero) which indicates a negative value. Net weight RAROC returns the result to investment in Bank Syari'ah Mandiri showed that the total profit has been adjusted to the higher risk than the average expected losses (unexpected loss). This means that BSM reflects the high level of profitability on the utilization and productivity of investment (Prabowo, 2009, p. 103).

This paper elaborates on the form of investment considered suitable to be Islamic bank products, in particular mudharabah investment products with certain results. These products fall into the category of fund (funding) products. The tendency of Islamic banks to provide murabaha financing products with the advantage of certainty gives time to Islamic banks that can give assurance of profit sharing. This could be an attempt to absorb funds from the public. This product complements the design of mudaraba products such as giro, savings and deposits. Mudharabah contracts do not give assurance of the profit sharing, and most importantly, do not infringe on the provisions of Islamic sharia. This research uses a descriptive qualitative method to describe the research subject. In this case, this is a product form of third-party funds that use mudharabah in Islamic banks as well as mudharabah investment product development for definite results in Islamic banking.

It is necessary to make innovations in introducing new product designs with the aim of stimulating public interest in sharia financial institutions, particularly sharia banks. There are two main problems faced by the Islamic banking industry in product fund raising: first, product raising funds of Islamic banks resemble conventional bank products, and differ only in their accordance with sharia principles; second, product 
raising funds in the Islamic banks are not maximized to absorb funds from the public.

\section{Sharia Banking}

Along with the improvement and reform of national banks after the economic crisis, sharia banking, as part of the national banking system, began to enter a new phase of implementation of the national banking system with all the obstacles and progress on a regular basis to be fixed in accordance with Islamic law. The sharia banking reform era began with the passing of Act 10 of 1998 on sharia banking (Syafi'i, 2001, p. 26), which was later refined through the sharia banking law No. 21 in 2008. The basic idea of the Islamic banking system is quite simple. The operation of Islamic financial institutions is primarily based on the principle of PLS (profit-and-loss-sharing). This profit sharing principle in Islamic finance is highly recommended and is an appropriate solution to the problem of allocation of limited funds, either in the form of loans or savings funds with the intention that management and financing can effectively be achieved. Islamic banks do not charge interest, but invite participation in the activities they fund. Depositors also equally share the profits with banks in accordance with a predetermined ratio. Thus, there is a partnership between the Islamic bank and the depositors on the one hand, and between bank customers as the investment managers of the resources of depositors in various productive business on the other (Algaoud and Lewis, 2001, pp. 9-10).

Reasons for the establishment of Islamic banks are based on the principles of justice practiced by Islamic banks. Among Western investors, there has been a paradigm shift in which they no longer invest for reasons that apparently focus on interest and profits. Now, they are more critical of income that may be obtained through the method of institution in 
screening the money, so that the sharing system implemented by Islamic banks is deemed more logical and fair for them. With Islamic banks, then, all people, especially Muslims, avoid usury in their muamalah activities to obtain inner and outer well-being and in accordance with their religious beliefs. The Shariah banking system operates on the principle of profit sharing and provides an alternative banking system that is mutually beneficial for the community and the banks - one which highlights fairness in transactions and ethical investment, promotes the values of solidarity and partnership in production, and avoids speculative activity in financial transactions. By offering a range of diverse banking products and services with more varied financial schemes, sharia banking has become an alternative banking system that is credible and can be enjoyed by all segments of Indonesia society (Bank Indonesia, 2013).

Islamic banks are known for their profit-sharing system and range of products that use mudharaba and musharakah contracts, which are considered to be fairer for all parties. However, there has been a shift in the Islamic banks, and murabahah financing products are favored, which provide definite results. This can seen in the Islamic bank financing ratio used in mudharabah and murabahah contracts. Based on the statistics of Bank Indonesia, the amount of financing disbursed by the shariah banking industry until October 2013 was valued at Rp179,28 trillion, up $32.23 \%$ from Rp135,58 trillion in the same period the year prior (Bisnis Indonesia, 2013).

Table 1. Sharia Bank Financing Products

\begin{tabular}{|c|l|c|c|}
\hline No & \multicolumn{1}{|c|}{ Contract } & March 2014 & April 2014 \\
\hline 1 & Mudharabah & 13.498 & 13.802 \\
\hline 2 & Murabahah & 111.727 & 112.288 \\
\hline
\end{tabular}

* in billion rupiah, Source: Islamic Banking Statistics (OJK, 2014, p. 30) 
As seen from the data above, there is significant difference in the number of financing system products using mudharabah and murabahah contracts. The decision of Islamic banks to preference the use of murabaha products is because this covenant is to give credence to the rate of return. Islamic banks also have not been so bold as to take risks, as in using mudharabah. In terms of the third-party funds, funding products with different instrument contracts are used. Commonly these are wadiah and mudharabah contracts, which are fundraising products that draw on current accounts, savings, and term deposits. From these, banks were not able to draw many customers to achieve their long desired 5\% market share.

At the end of 2014, the total assets of Islamic banking is expected Rp 255,2 trillion (pessimistic), Rp 283,6 trillion (moderate) and a maximum of Rp 312 trillion (optimistic) while total deposits are expected in the range $\mathrm{Rp} 209,6$ trillion (pessimistic), Rp 220,7 trillion (moderate) and Rp 232,8 trillion (optimistic) and, the total financing will reach the minimum Rp 216,7 trillion (pessimistic), Rp 228 trillion (moderate) and maximum Rp 239,5 trillion (optimistic). Based on these three scenarios, the market share of Islamic banking by the end of 2014 is estimated between 5.25\% -6.25\% (Bank Indonesia, 2013, p. 19). Sharia banking market development efforts undertaken by the Bank Indonesia and industrialists who are members of the $\mathrm{iB}$ Campaign were able to increase the market share of sharia banking in the banking map to achieve $\pm 4.8 \%$ as of October 2013, with the number of sharia bank accounts reached \pm 12 million accounts or $9.2 \%$ of total number of national bank accounts (Bank Indonesia, 2014). Viewing the movement of the sharia banking trip as such signals that more effort is required for the better growth of sharia banking to build public interest to choose shari'ah banking products. 


\section{Fundraising Products of Sharia Banks}

Deposit/savings services are held in the form of bound and not bound deposits/savings over a period of time, with certain conditions for investment and withdrawal. In connection with, the type of deposits/ savings that can be collected by sharia banks varies according to need and convenience. Fundrising in the Islamic bank can take the form of demand deposits, savings and time deposits. Mudharabah wadiah is the operational principle of sharia applied in fund raising and society more broadly (Muhammad, 2005).

Generally wadiah is a pure deposit of the depostor (muwaddi) who has goods or assets in the depositary (mustawda) under trust/confidence, between both the individual and the legal entity, where goods entrusted must be protected from damage, loss, security, and integrity, and may be at any time restored. The contract pattern of wadiah is twofold; wadiah yad amanah and wadiah yad dhamanah. Wadiah yad amanah (hand trust), is a form of deposit, where the parties receiving deposits are not responsible in case of loss or damage caused to the assets deposited as long as the loss or damage is not the result of negligence in maintaining the consignment (for factors beyond its limits). The wadiah yad dhamanah (hand insurer) is a form of deposit in which the party receiving the deposit is responsible for any loss/or damage to the consignment (Muhammad, 2008, p. 8).

The wadiah principle applied in Islamic banking is wadiah yad dhamanah, which is applied to checking accounts. Dhamanah wadiah differs from wadiah amanah. In wadiah amanah, in principle, entrusted property may be used by the entrusted. While in the case of wadiah dhamanah, the entrusted party (bank) is responsible for the integrity of the assets deposited so that it can take advantage of the deposited treasure. Because the product is applied in banking current accounts, it is also attributed with yad dhamanah, with same implication as qard, in which the 
customer acts as the money lender, and the bank acts as the lent. In doing so, this is much like the practice of Zubair bin Awwam when receiving deposits at the time of the Prophet (Karim, 2006, p. 108).

Briefly, mudharabah, or capital investment, is handing money to people who are trading so that they get a percentage of the profits. As a form of contract, mudharabah is an agreement for the results when the owner of the funds/capital (investors), commonly called shahibul maal, provides $100 \%$ of the capital to the party who is able to manage the socalled mudharib, to undertake productive activities with the proviso that the resulting profits will be divided according to the predetermined agreement in the contract (the amount of which is also influenced by market forces). To apply the principle of mudharabah in sharia banking, the depositor acts as shahibul maal (owners of capital) and banks as the mudharib (managers). The funds are used by banks to make murabahah or ijarah as described earlier. The funds can also be used to perform mudharabah for the second bank. The results of these efforts will be divided and generated based on an agreed ratio (Muhammad, 2013; cf. Mohd Jaffar, 2010). Savings products in Islamic banks have been regulated in the National Sharia Board Fatwa No. 2 / DSN-MUI / IV / 2000 on savings; while products related to mudharabah in Islamic bank deposits have been stipulated in the National Sharia Board Fatwa No. 03 / DSN-MUI / IV / 2000 on deposits.

\section{Mudharabah Investment}

Mudharabah is derived from the word adh dharbu fil ardhi, namely travel for trade affairs. Alqur'an sura 73 verse 20 states, "They travel through the earth seeking the gift of God." Known qiradh also derived from the word al-qardhu which means al-qath'u (pieces), because the owner cuts off part of his property to be traded and acquire most benefit (Sudarsono, 2010, p. 67). Technically a mudharabah venture is a partnership contract 
between two parties in which the first party (shahibul maal) provides the entire capital, while the other party is its business manager. The profit of mudharabah is divided by the agreements set forth in the contract, whereas if the loss is borne by the owners of capital loss was not due to the negligence of the management. If losses are caused by fraud or negligence of the manager, the manager should be responsible for the losses (Sudarsono, 2010, p. 67).

Jurists agree on the permission of shirkah mudarabah. The skill is also based on the ijma and is anchored in the verses of the Qur'an and the hadiths of the Prophet. In addition, the human race requires it because not all people who have wealth have expertise in utilizing and developing the property. Likewise, not all people are able to develop their property and do the work although they have the capital. Thus, the existence of shirkah mudharabah may help to realize the benefits for both parties (Ath-Thayyar, 2009; cf. Hakiem and Waluyo, 2011).

Financing available through sharia banking is an excellent product that should be developed by sharia banks. Mudharabah financing is very relevant in any effort to increase productivity by providing real sector financing to increase the potential of businesses, especially SMEs in increasing quantity and quality of production. In fact, however, financing products are greatly feared by sharia banks as they prefer murabahah products that generate the most profit for sharia banks. This is not independent of the magnitude of the risk on the financing of mudharabah, whereas murabahah contracts tend to have a smaller risk than those of financing (Iskan, 2012).

The essential difference between musharakah and mudharabah is in the contribution of upper management and finance. In mudharabah, capital comes from one party, whereas in musharakah the capital is derived from two or more parties. Musharakah and mudharabah in jurisprudence 
literature are shaped by trust agreements which require a high level of honesty and justice. Therefore, each party should maintain honesty for the common good and every effort should be made by each party to avoid committing fraud and/or inequitable distribution of income, as these are not in accordance with Islam. Briefly, mudharabah or capital investment is handing money to people who trade so that they get a percentage of the profit. As a form of contract, mudharabah is an agreement on results, when the owner of the funds/capital (investors), commonly called shahibul maal, provide $100 \%$ of the capital to a second party who is able to manage the so-called mudharib to undertake productive activities with the proviso that the resulting profits will be divided between the two parties according to a predetermined agreement in the contract (the amount of which is also influenced by market forces) (Muhammad, 2005, p. 90).

The word investment derives from the English to invest, meaning to plant. In the Comprehensive Dictionary of Economics, investment is defined as the currency exchange with other forms of wealth such as stocks or immovable property which is expected to be held for a certain period of time in order to generate revenue (P3EI UII, 2008). While some economists define investment as a commitment of money that is expected to generate of additional money (Farizal, 2010). A form of investment must be protected from doubtful or haram business dealings or transactions. Halal also concerns the use of transacted goods or services; examples of industries are considered forbidden (haram) include: the alcohol industry, the pornography industry, financial services usury or gambling. Procedures should also be protected from things that are doubtful or illicit. In addition, halalness also includes a person's intentions when transacting and during the transaction implementation procedure. Halal is also linked with intention or motivation. Motivation must be towards a lawful transaction that is oriented to results that can provide benefits to the parties involved (OJK, 2014). 
Maslahah (benefit) is essential in all muamalah actions. All parties involved in the investment must be able to benefit in accordance with their portion. For example, the benefits that arise must be perceived by the parties to a transaction and must be perceived by the general public. Basically, economic actors will be oriented to achieve this maslahah and prefer that maslahah will preferably be greater than less. A higher maslahah amount or level is preferable to a lower maslahah amount or level or greater maslahah stability will provide a higher level of happiness, therefore it is preferable that maslahah is smaller. Maslahah continuously increases over time. This concept is often referred to as quasi concavity, in which maslahah shows a non-decreasing pattern. In the case of illness, for example, a person will strive to treat the pain, because the pain is not pleasant and can reduce one's level of life satisfaction. Furthermore, a person is willing to sacrifice, such as through exercise, vaccinations, and sensible diet, so as not to fall ill again and to be healthier in the future (OJK, 2014).

\section{Funds in Sharia Banking}

Table 1. DPK Composition in Islamic Banks and Sharia Business Units

\begin{tabular}{|l|c|c|}
\hline \multicolumn{1}{|c|}{ Indicator } & May 2013 & May 2014 \\
\hline 1. Giro IB Wadiah & 15.689 & 13.978 \\
2. IB Saving & 47.423 & 55.801 \\
a. Wadiah contract & 8.265 & 10.728 \\
b. Mudharabah contract & 39.159 & 45.073 \\
& & \\
\hline
\end{tabular}




\begin{tabular}{|l|c|c|}
\hline 3. IB deposit- Mudharabah & & \\
contract & 100.746 & 115.728 \\
a. 1 year & 64.071 & 81.064 \\
b. 3 year & 23.233 & 20.887 \\
c. 6 year & 6.423 & 4.845 \\
d. 12 year & 7.014 & 8.927 \\
e. > 12 year & 5 & 5 \\
\hline Total & $\mathbf{1 6 3 . 8 5 8}$ & $\mathbf{1 8 5 . 5 0 8}$ \\
\hline
\end{tabular}

*in Billion Rupiah (Source: Statistics Islamic Banking FSA 2014)

The focus here is on fund raising products that use mudharabah, and which are located on savings and deposit products. In May 2013, Mudharabah savings products amounted to 39159 billion rupiah and Mudharabah deposits amounted to 100746 (billion). Further, in April 2014, mudharabah savings products were valued at 45.073 (billion), and mudharabah deposits at 115728 (billion).

Mudharabah product development

\section{Mudharabah Savings}

45073-39159 / $39159 \times 100 \%=15.102 \%$ per year

$15.102 \% / 12=1.26 \%$ per month

2. Mudharabah Deposits

$115728-100746 / 100746 \times 100 \%=14.871 \%$ per year

$14.871 \% / 12=1.24 \%$ per month

If seen from the development of products that use the mudharabah fund rising. Monthly growth was around one percent and did not exceeded two percent. Product funding innovations are therefore required in order to achieve a better market share and a forum for which people can invest according to sharia. 
Mudharabah investment products are investments that fall into the category of products that raise funds from the public. Investment products can complement existing funding products (checking, savings and term deposits). Mudharabah investment products for definite results that form of investment at Big Islamic bank customers who have more funds after the bank has obtained the submission of the financing already deal of customer financing (creditors). If during the Islamic bank financing products like and more frequent use of murabahah product that is certain profit margin, it is now time Islamic banks also offer products that can provide funding with definite results for clients with capital so that they can gain a greater market share (Muhammad, 2005).

Example: Mr. Ahmad applied for a home loan at Sharia Bank of 300 million using a murabahah contract agreement with a period of 12 months. The Islamic bank determined the margin of financing was $\$ 100$ million for 12 months, until the end of the contract. In financing that is certain, the bank will profit by 100 million over 12 months. Then, the Islamic bank offers project financing to investment customers. Investments can be offered to individual and groups / collectives. This is a mudharabah investment contract with an already agreed upon its ratio. Since the project/ financing is definite, the rate of return for the outcome is certain.

The profit sharing ratio between the customer and the bank is agreed on (50:50), which means that the bank will gain overall on the settlement cost + margin, 300 million +100 million $=400$ million over 12 months. Monthly installments of 400 million / $12=33,333,333$ million per month, which consists of monthly installments of principal installments and margins. Principal installments of 300 million over 12 months, which is 25 million per month and results in big profits per month $33,333,333-25,000,000=8,333,333$. Then, the monthly benefit that is shared between the customer and the bank as the agreed ratio of 
50; 50 , is $8,333,333 / 2=4,166,666$. The total amount received monthly from the investor, ie. the number of monthly principal installments + margin amounts to $25,000,000+4,166,666=29,166,666$. If the total revenue that the investor during the year is $29,166,666 \times 12$ months = $349,999,998$. Meanwhile, as for the profits of banks during the year is $49,999,998(4,166,666 \times 12=49,999,998)$.

The above calculation is fantastic, and highly favorable for both the Islamic bank and investor customers. The project will then be offered to people who have capital to invest, with returns for definitive results. The results are in accordance with the agreement between banks and investors. The choice of mudharabah investment offers certainly that results will be much greater than the deposit. It would be an additional instrument in absorbing funds. Mudharabah investment products can be done with the provision that the Islamic bank already has a project financing deal, that is the mudharabah investment has been to provide certainty on the magnitude of the results returned to the investor. The possibility of risk, however, remains because investment cannot be separated from profit and risk. The nominal amount of investment must in accordance with the policies and regulations of the Islamic bank.

\section{Conclusion}

In the third party to collect funds Islamic bank using a product that is not much different from conventional banks, only located on the suitability of the provisions of sharia. These products include giro, savings and deposits, but in fact the development of this product is not so significant in absorbing public funds as can be seen from the market share of Islamic banks which has not reached 5\% of the determined target. In doing so, product innovation in third-party funds, such as mudharabah investment products sharing definitely is required. 
Application Sharing Mudharabah Investment products must have an alternative in raising third-party funds in Islamic banks. These investments are profitable for the customers holding the funds and the Islamic banks. These investments provide certainty of results despite using mudharabah. This investment is based on the certainty of the project or financing as has been agreed by the Islamic bank and the creditors. These investment products can be offered to customers as both individual and groups / collectives. 


\section{References}

Algaoud, Latifa M. dan Mervyn K. (2001). Lewis, Perbankan Syariah, Prinsip, Praktik, Prospek, Jakarta, PT. Serambi Ilmu Semesta.

Anisah, Yuli. (2012). Pengaruh Sistem Profit Sharing Terhadap Keinginan Nasabah Untuk Berinvestasi Pada Baitul Maal Wa Tamwil (BMT) Di Kota Banda Aceh. Jurnal Ekonomi Dan Bisnis Vol. 12, No. 1. Lhokseumawe, FEB Politeknik Negeri Louksumawe.

Bank Indonesia. (2013). Outlook Perbankan Syariah 2014. Jakarta.

Bisnis Indonesia. (2013). Outlook Perbankan 2014: Industri Syariah Bakal Terkoreksi, retrieved from http://insco.co.id/?p=1264http:// insco.co.id/?p=1264 August 26, 2014.

Farizal. (2010). Pengembangan Kompetensi SDM Perbankan Syariah Melalui

Corporate University. Forum Riset Perbankan Syariah II.Y ogyakarta.

Karim, Adiwarman. (2006). Bank Islam Analisis Fiqih dan Keuangan Edisi Ketiga, Jakarta: PT. Raja Grafindo Persada.

Hakiem, Hilman dan Desi Sulfiaratih Waluyo. (2011). Musyarakah, Mudharabah dan Pertumbuhan Sektor Riil. Jurnal Ekonomi Islam ALInfaq Vol. 2. No. 1. Bogor: Program Studi Ekonomi Islam Fakultas Ilmu Agama Islam Universitas Ibnu Khaldun.

Iskan, Syukri. (2012). Sistem Perbankan Syariah Di Indonesia Dalam Perspektif Fikih Ekonomi. Yogyakarta: Fajar Media Press.

Mohd Jaffar, M. (2010). Mudharabah and Musyarakah Models of Joint Venture Investment between Two Parties 2010, CSSR 2010, International Conference on Science and Social Research 5773816, pp. 42-47.

Muhammad. (2013). Manajemen Keuangan Syariah. Yogyakarta.

Muhammad. (2008). Sistem dan Prosedur Bank Syariah, Yogyakarta: UII Press. 
Muhammad. (2005). Manajemen Bank Syariah, Yogyakarta: UPP AMP YKPN.

Ath-Thayyar, Muhammad Abdullah bin et.al. (2009). Ensiklopedi Fiqih Muamalah Dalam Pandangan 4 Madzhab. Yogyakarta: Maktabah AlHanif.

Prabowo, Yudho. (2009). Analisis Resiko dan Pengembalian Hasil pada Perbankan Syariah: Aplikasi Metode VaR dan RAROC pada Bank Syariah Mandiri. Jurnal Ekonomi Islam La_Riba Vol. III. No. 1.

P3EI UII. (2008). Ekonomi Islam. Jakarta: Raja Grafindo Persada.

Otoritas Jasa Keuangan, Statistik Perbankan Syariah, (2014). Jakarta.

Otoritas Jasa Keuangan. (2014). Materi Training of Trainers Perbankan Syariah. Solo

Sudarsono, Heri. (2010). Bank \& Lembaga Keuangan Syariah Deskripsi dan Ilustrasi Edisi 3. Yogyakarta: Ekonisia.

Syaf'i, Muhammad Antonio. (2001). Bank Syariah: Dari Teori ke Praktik, Jakarta, Gema Insani Press.

The Holy Qur'an Text and Translation (transl. Abdullah Yusuf Ali). (2007). Kuala Lumpur: Islamic Book Trust. 
Vol. 1 No. 3, September - December 2016 